\title{
EXCERPTS FROM THE DEVELOPMENT OF METHODS OF LEGAL INTERPRETATION
}

\author{
Zoltán J. TóTH ${ }^{1}$
}

Legal interpretation is a stage in the application of the law, an indispensable operation whereby a judge (or other decision-maker) determines what a legal text means. The text does not stand alone; the words and expressions used in the norm may themselves have multiple meanings even in the context of everyday terminology, not to mention the differences between legal and other professional meanings. Furthermore, a norm has not only a text but also a context, a regulatory environment, a declared legislative purpose, an intention by the lawmaker or a set of moral expectations within which the text can be interpreted, etc. This paper attempts to present how methods of legal interpretation have evolved over the last two centuries and how we have moved from Savigny's Canon to the sophisticated methodologies of today. At the end of the paper, we ourselves will attempt to provide a useful methodological classification of these highly fragmented and diffuse methods.

\begin{tabular}{l|l} 
Statutory interpretation \\
legal argumentation \\
legal methodology \\
history of ideas \\
Savigny \\
Bielefelder Kreis
\end{tabular}

\section{Introduction}

Before studying the development of legal interpretation methods ${ }^{2}$ in detail and delineating the evolution of the theoretical history of the relevant methodology, we should clarify what we mean by 'interpretation' because it determines the subject of our examination and the scope of our analysis.

1 | Professor, Department of Legal History, Jurisprudence, and Church Law, Faculty of Law, Károli Gáspár University of the Reformed Church, Budapest, Hungary, toth.zoltan@kre.hu.

2 | The present paper is concerned with the presentation of (important aspects of) the development of the theory of methods of legal interpretation, i.e. it is essentially descriptive. Matters of the empirical use of the methods presented and the evaluation of the appropriateness of these methods have been and are dealt with elsewhere. 
There is a difference between the concepts of legal interpretation and legal argumentation (legal reasoning). Legal interpretation is the exploration of the meaning and/ or the reason of a legal norm in a specific case, while legal argumentation is a subsequent attempt to justify the application of the norm (in a given way and with a given meaning). Essentially, it is a probabilistic reasoning to prove the premises on which the decision is based are suitable to justify the decision, and they lead to a rationally defensible (though not necessarily the only possible) conclusion. ${ }^{3}$ As Neil MacCormick formulated it, interpretation is a particular form of practical argumentation in law, in which one argues for a particular understanding of authoritative texts or materials as a special kind of (justifying) reason for legal decisions'. ${ }^{4}$ Interpretation is a 'rational'5 activity whereas argumentation is a 'rationalising' ${ }^{\prime}$ one. ${ }^{7}$ In the case of the latter, the focus is more on the power of persuasion rather than on logic, and all arguments are acceptable which are suitable for this persuasion. ${ }^{8}$

According to Wróblewski, legal interpretation can be considered at three levels. In the broadest sense ('largissimo sensu'), it covers the understanding of all 'cultural objects', i.e. things or phenomena created by humans. In the broad sense ('sensu largo'), this concept only includes the interpretation of expressions of the written or spoken language or any manifestation thereof. Finally, in the strict sense ('sensu stricto'), we use this concept to explore the meaning of a text only if we have doubts about the 'correct' meaning thereof, and we wish to explore this 'correct', but at first sight not obvious, meaning. ${ }^{9}$ Below, we use the latter, the strict sense of the concept of 'interpretation' and wish to draw the arc of the development of the theoretical history of these methods by analysing and delineating the relevant jurisprudential works on this subject.

3 | Argumentation is the prevention of rebuttal, the weakening of the persuasive force of possible opposing views, and, thus, the confirmation of the correctness of the position on which the decision is based.

4 | MacCormick, 1995, p. 467. For the issue of interpretation as a part of argumentation, see, additionally, e.g. Gebauer, 2000, p. 683; Scallen, 1995, p. 1731. and footnote 119 in p. 1734; Jakab, 2013, pp. $1219-1220$ and $1230-1231$.

5 | The interpretation of statute law is based on the assumption that the legislator is rational. Statute law is deemed to be a reflection of coherent and logical thought. [...] A rational approach to the interpretation of statutes involves constructing and weighing arguments against one another. (Devenish, 1991, p. 225.)

6 | Legal reasoning does not only involve purely rational arguments but also the evaluation of conflicting interests and the making of value judgements which depend on prevailing legal and moral values and very often on common sense. (Devenish, ibid.)

7 | However, this does not mean that ex post justification cannot be logically justified.

$8 \mid$ This is the summary of the main types of these arguments by Hoecke and Ost: 'While argumentation theory partly encompasses the interpretation theory, it is broader, because it covers all acceptable argumentation strategies outside statutory interpretation, such as references to the authority of court decisions, of doctrinal writers, of sources from foreign legal systems, or of non-legal persons or sources (e.g., religious or political ones). It also covers the argumentation as regards personal evaluations and normative standpoints [...]. In all these cases, the underlying paradigmatic theory determines which kind of arguments and which argumentational strategies are considered to be acceptable within legal reasoning.' (Hoecke and Ost, 1998, p. 198.)

9 | Cf.: Wróblewski, 1969, p. 4. 


\section{The appearance of the matter of legal interpretation in the field of jurisprudence}

At the beginning of the formation of techniques used for regulation of behaviour by written norms, even in Roman law considered to be the most advanced among ancient legal systems (and for a long time thereafter), only two quite diffuse 'methods' were distinguished: the grammatical/literal interpretation and the interpretation based on equity (aequitas) (often called the only 'logical' interpretation) ${ }^{10} .{ }^{11} \mathrm{Hence}$, two extreme views clashed in interpretation disputes: whether, in the case of literal meaning leading to 'unfair' or 'wrong' result, we should insist thereon for legal certainty and predictability or, considering the aspects of righteousness of cases, we should depart therefrom for a more important purpose and make a 'more proper', more equitable decision assuming the representation of a substantive value.12 In the Middle Ages and the Modern Period, several different summaries were developed about the arguments, topical maxims, and reasoning tricks ${ }^{13}$ (often only incidentally related to the issue of legal interpretation) usable in the course of legal argumentation (some of them known as legal logical formulas nowadays); however, these arguments were only accidental and had no system.

The first elements of a later coherent system appeared at Hugo Donellus (1527-1591) who also distinguished two interpretation methods: the 'grammatical', which establishes the literal meaning (littera legis) of the text of the statute, and the 'logical' which determines the sense or reason (ratio legis) of the statute. It is always the latter one which is significant because the sentential legis, the (real) meaning of the statute, is what is binding and not the mere letter. If the grammatical meaning covers the 'real' meaning, the grammatical meaning will, of course, be proper but only because it is identical to the meaning reached through logical interpretation. However, if the former one tells us more or less than the latter, grammatical meaning must be amended by the 'logical' (actually substantive) interpretation: it must be tightened (interpretatio restrictiva - restrictive interpretation) or expanded (interpretatio extensiva - extensive interpretation). It was 'duplex interpretatio'14 which fundamentally determined the subsequent legal thinking

10 | Cf.: Szabó, 1960, pp. 100,124,146 and 153.

11 In the course of applying the Roman law, many specific techniques were used in the practice to determine the 'proper meaning' but there was no attempt to classify them into a methodological system. Although, there were and there are Roman law specialists (taking, primarily, disciplinary aspects into account) who, still today, provide a systematic description of the interpretation methods of Roman law. Also using the system theory results of the twentieth century, András Bessenyő has such a retrospective approach and recognises three basic interpretation schemas in Roman law: the grammatical-logical interpretation (interpretatio grammatico-logica), the historical interpretation (interpretatio historica), and the systemic interpretation (interpretatio systematica). (Cf.: Bessenyő, 2003, pp. 23-24). On the contrary, e.g. András Földi and Gábor Hamza delineate the classification of Savigny being used even today but also add that the setting up of this classification is expressly the result of the modern legal dogmatic. (Cf.: Földi and Hamza, 1996, pp. 73.)

12 | For the nature of this dilemma permeating ancient and medieval thinking, see: Vékás, 1998, pp. 3-19 (in particular part I of this study, pp. 3-6); and for details of the contemporary concept of Roman law, see: Maine, 1861, pp. 39-58.

13 | For the most important ones in England, see: Holdsworth, 1938, vol. XII, pp. 188-191.

14 | For the methodological concept of Donellus in Hungarian, see: Kiss, 1909, pp. 30-31. 
for centuries, ${ }^{15}$ insomuch that even after Savigny, who made a breakthrough in the legal hermeneutics, several legal scholars analysed the possible types of interpretation of legal texts on the basis thereof for decades, sometimes also adopting the errors of the thinking of Donellus and mixing up the methods of interpretation with the results thereof.

Hence, long after the categorisation of Savigny, Bernhard Windscheid (1817-1892) also distinguished two interpretation methods: the grammatical ('grammatische Auslegung') and logical interpretation ('logische Auslegung'). Windscheid says that interpretation is nothing else but the 'establishment of the content of law'16 and, according to him (similar to Donellus), we can reach it not through the grammatical processing of the text but through the establishment of the real meaning thereof. The grammatical meaning merely tells us what the words of legal norms in themselves or in the light of the concrete case to be decided by the judge mean, but it does not provide real support to establish the proper meaning when the text has no reasonable meaning or, more frequently, when it has several reasonable meanings. ${ }^{17} \mathrm{~A}$ further problem is that the grammatically proper (understandable) meaning may be incorrect in content (i.e. wrongly worded) which, in such a case, must be tightened or expanded, or changed by the judge. ${ }^{18}$ It must be done by the interpretation called (also) by Windscheid 'logical', which has two main techniques (having not too much to do with real formal logic): the examination of legislative history of the given statute (i.e. the legal and social circumstances of the creation of the new legal regulation) and the determination and enforcement of the purpose which the lawmaker intended to reach with that. ${ }^{19}$ We can see that, according to Windscheid, 'logical' interpretation is actually the synonym of the 'non-grammatical' interpretation which has the techniques known today as 'historical' and 'teleological' as its main (but not only) methods.

Two decades later, Ferdinand Regelsberger (1851-1911) expressed a similar opinion. ${ }^{20}$ He also thought that two types of interpretation existed: grammatical and logical. While the former (which has to be the starting point of all interpretations) explores the meaning of the words used by law on the basis of ordinary or special legal language (if any), ${ }^{21}$ the

15 | The duplex interpretatio (in its strict sense) did not mean a methodological classification but a classification according to the result of interpretation. All these may be tracked back to the axiological, therefore eventually, ontological issue of whether only righteous law can be law. It roots in Roman law where this problem manifested in the opposition of ius strictum and ius aequum (for the relations between the two approaches and their consequences regarding the applicability of the positive law, see e.g.: Tóth J., 2016, pp. 119-120.) and its general legal theoretical consequences materialised in the contradiction between natural law and positive law (which cannot be discussed here even briefly) and later in appearance of human rights and constitutional rights above statutory law.

16 | 'Auslegung ist Darlegung des Inhalts des Rechts.' (Windscheid, 1873, p. 49.)

17 | Windscheid, 1873, p. 51.

18 | Hiernach ist die berichtigende Auslegung entweder einschränkend, oder ausdehnend, oder abändernd. (Windscheid, 1873, p. 53.)

19|'Im Besonderen ist hier zweierlei hervorzuheben: der zur Zeit der Erlassung des Gesetzes vorhandene Rechtszustand, ... und der Zweck, welchen der Gesetzgeber mit seinem Gesetze hat erreichen wollen.' (Windscheid, 1873, p. 52.)

20 | However, a significant conceptual difference regarding the true nature of analogy existed between them: Windscheid considered it to be an independent operation of interpretation but Regelsberger did not. (Cf.: Windscheid, 1873, pp. 54-58; and Regelsberger, 1893, pp. 155-161.)

21 | Regelsberger, 1893, pp. 145-146. 
latter controls this meaning and extends or tightens it if necessary. ${ }^{22}$ In the course of that, it takes the following into consideration: i) the comparison between the meaning and the statute in question as a whole, the laws on similar subject ('related' laws), and all legal norms regarding a legal institute or the moral and social tasks of the law ('die sittliche und soziale Aufgabe des Rechts'); ii) the purpose of the law ('der Zweck des Gesetzes', 'ratiolegis'); iii) the 'higher principles' ('höhere Prinzips', 'ratio juris'); iv) the historical basis ['geschichtliche Grundlage' (i.e. the contemporary social reason for the legislation)] of the given legal regulation; and v) the (subjective) will of the legislator ('der Willen des Gesetzgebers'). ${ }^{23}$ It is clear from the enumeration that Regelsberger also incorporated all operations aiming not explicitly at the establishment of the grammatical meaning into the 'logical' interpretation ('logische Auslegung'); hence, the interpretations are also called today as systematic-contextual, teleological, historical, and substantive. However, duplex interpretatio, the method of Donellus, prevailed not only in the German but also in the English-speaking world. This is proved by the fact that even the summarising work ${ }^{24}$ (not affected by the theories of Savigny, Jhering, Heck, or their followers) of the Englishman Thomas Erskine Holland (1835-1926) published long after the turn of the century knew only two types of methods in the course of 'doctrinal interpretation' regarding both the private and public law: the grammatical interpretation and the logical interpretation. ${ }^{25}$ Further, similar to the German pandectists and legal philosophers of the Modern Ages, he defined the latter as the reference basis of the literal meaning. ${ }^{26}$ Finally, as for the Hungarian legal academics, this theory was also followed, inter alia, by Ignác Frank ${ }^{27}$ in the middle of the nineteenth century and by Imre Zlinszky ${ }^{28}$ and Béni Grosschmid ${ }^{29}$ at the beginning of the twentieth century.

22 | 'Ausdehnende Auslegung' (interpretatio extensiva) and 'einschränkende Auslegung' (interpretatio restrictiva). (Cf.: Regelsberger, 1893, pp.152-154.)

23 | Regelsberger, 1893, pp. 147-151.

24 | Holland, 1916.

25 | Cf.: Holland, 1916, 425 and 432.

26 | Furthermore, he also distinguished extensive and restrictive interpretation depending on the possible result of this comparison. (Cf.: ibid.)

27 | According to Frank, 'the scientific explanation is coming from the words of the statute or from the reasons thereof and, accordingly, it is word-explaining or reason-explaining (grammatica vel logica)'. (Frank, 1845, p. 59.) However, he classified not only the mere grammatical meaning to the former one but also the meaning called 'systematic' in the modern legal literature; while he considered the latter as a kind of mixture of today's historical and teleological interpretation;, in case of collision, he considered the 'logical' meaning as primal. (Cf.: Frank, 1845, pp. 60-61.)

28 | Zlinszky also classified the modern concept of historical, systematic, and teleological interpretation to the 'logical explanation' (but, similar to Frank, did not use formal logical rules) but he never said that the latter methods were only the accessories or corrections of grammatical interpretation; on the contrary, these were to be applied together with the grammatical interpretation and even the grammatical meaning could depend on the latter ones. (Cf.: Zlinszky, 1902, p. 30.)

29 | Contrary to Zlinszky, Grosschmid completely accepted the view according to which two types of methods exist; and the logical (or 'cause investigating') interpretation (interpretatio logica) is secondary to the grammatical (or 'word investigating') interpretation (interpretatio grammatica). (Cf.: Grosschmid,1905, pp.940-941.) However, he uses the concept of 'logical' explanation in a much stricter sense than his contemporaries; since he considers that it means only the exploration of the subjective historical intention, psychological will of the legislator. '... it is not the word of the statute that obliges but the will of legislator. And the final purpose and the task are always the finding and the determination of the real will.' (Grosschmid, 1905, p. 941.) 


\section{Savigny's canon of methods of interpretation}

The common feature of all these theories was that they had no coherent hermeneutical methodology, but, enumerated, similar to the classical period of the Roman law, the possible methods of interpretation of legal texts in an incidental and arbitrary manner and, reduced the interpretation to the analysis whether the literal meaning of the written norm is identical to any meaning which moved away from the text (to a meaning extractable from the text or even independent from that, i.e. 'external' meaning). Until the middle of the nineteenth century and-as we could see-also for a while after Savigny, there was no outstanding theory which would endeavour to explore systematically and present the different methods of legal interpretation used in the practice. Friedrich Carl von Savigny was the first who attempted to define, distinguish, and systematise the main methods in brief in Volume I of his work ‘System des heutigen Römishen Rechts' published in 1840. According to Savigny, the interpretation has four main methods: grammatical, logical, systematic, and historical interpretation..$^{30}$ The grammatical interpretation (interpretatio grammatica; ${ }^{31}$ 'das grammatische Element der Auslegung') explores the general meaning of the words, expressions, sentences, the text as a whole, and the conjunctions which are attributed to the given word, expression, etc. by an ordinary person who knows the given language well. The logical interpretation (interpretatio logica; 'das logische Element [der Auslegung]') uses the formal rules and logical principles of thinking to determine what the text of a legal norm means (or does not mean). Through systematic interpretation ${ }^{32}$ (interpretatio systematica; 'das systematische Element [der Auslegung]'), a conclusion regarding the meaning of a legal provision can be drawn from its position in the system of legal norms, and the type and function of the surrounding legal norms. In the course of historical interpretation (interpretatio historica; 'das historische Element [der Auslegung]'), we try to determine the real meaning of the legal norm with the help of the (probable) intention of the contemporary legislator creating the legal norm. ${ }^{33}$

Later, a fifth method, the teleological interpretation, also joined Savigny's canon of methods which were also adopted by Hungarian legal academics (e.g. Pál Angyal, Ferenc Finkey, and Károly Szladits) in the first half of the twentieth century. ${ }^{34}$ The basis of its use

30 | Savigny, 1840, vol. I, pp. 213-214.

31 | Savigny did not use the Latin names in the course of delineation the methods ('elements') of interpretation.

32 I Savigny did not discuss the interpretation methods in the order considered today as 'conventional' (and also followed in this research) but, firstly, he studied the historical 'element' of interpretation as the third method and defined systematic interpretation only after that as the fourth one.

33 | It is very important to mention that, according to Savigny, these methods do not compete with but complement each other, i.e. in a certain case, we do not apply either the one or the other (choosing the method actually best to apply) but all of them have to be applied because they can authentically determine the meaning of the text only together (Savigny, 1840, vol. I, p. 125). Furthermore, the meaning of the text cannot always be determined exactly; hence, we only have to try (but that we indeed have to try) to get the closest as possible to the true meaning of the text in the rich range of its meanings (Savigny, 1840, vol. I, p. 216).

34 | According to Pál Angyal, the four main interpretation methods are the grammatical, logical, historical, and systematic interpretation; For Finkey, these are the grammatical, logical, histori$\mathrm{cal}$, and systematic explanation; while Szladits, besides the classical four methods (grammatical, logical, systematic, and historical interpretation), also defined the evaluative interpretation as an independent fifth type of method. While, in the view of the two criminal law experts (Angyal and 
in law was the idea of Jhering according to which law is not a self-contained system to be examined for its own sake, ${ }^{35}$ but it contains norms which have tasks to be carried out and functions, i.e. (social) purposes, which have to be enforced by judges. ${ }^{36}$ This 'goal idea' was further developed by Philipp Heck, who assigned the judges to apply the results of the (also social) balance of interest of the legislator. ${ }^{37}$ According to Heck, the judge has the task of seeking the will of the legislator ('Forschung nach dem Willen des Gesetzgebers'), namely exploring what social needs the legislator took into consideration when creating the legal norm. However, this is not the search for the psychological will (subjective intention) of the 'realistic' legislator but for the causal factors creating the law, namely determining what was (could be) the original (objective) purpose of the statute in light of the historical circumstances of the creation thereof. ${ }^{38}$ Later, a complete legal theoretical trend developed from this view which was named, as in the title of the cited work of Heck, 'Interessenjurisprudenz' ('jurisprudence of interest') and which, contrary to the advocates of applying the subjective historical method of Savigny, stood firmly for the objective teleological method. ${ }^{39}$ Furthermore, there was one more interpretation method, the evaluative interpretation, the use of which arose, for certain authors, as a requirement (either as an independent method or as a special part of teleological interpretation) in the course of application of law (as the late successor of ius aequum in Roman law) from time to time. This method was the most accepted by theory during the blossom of Wertungsjurisprudenz ('jurisprudence of values'), ${ }^{40}$ and

Finkey), the content of the mentioned interpretation tools was mostly consistent with what Savigny thought about it (with the exceptions that Angyal says that the grammatical meaning did not mean the ordinary but the legal meaning and that the further, non-formal logical elements of 'logical' meaning of duplex interpretation are still present in the logical method), for Szladits, it is only true for the first three methods because he also considered the teleological interpretation not recognising it as an independent method but placing it partly into historical and partly into evaluative interpretation (which latter interpretation, by the way, takes substantive 'extent of correctness' into account). (Cf.: Angyal, 1909, pp. 104-105; Finkey, 1914, pp. 99-100; Szladits, 1941, pp. 155-156.)

35 I In his early works, Jhering says exactly the opposite thereof; moreover, this statement does not characterise the entire work of Jhering but only his works following his dogmatic-centric concept analyser period.

$36 \mid$ '... das Recht kennt nur eine Quelle: den Zweck.' (Jhering, 1877, p. XIII). Jhering also says that the content of the statute can be determined only through its purpose, i.e. the 'teleological further development' ('teleologische Entwicklung') of the (merely written) law: (Cf.: Jhering, 1877, p. 426.)

37 | 'The legal community has a strong interest in [the application of] the statute achieving the result which we expect from it [for which it was made] ...' (Heck, 1914, p. 59.)

38 | See: Heck, 1914, p. 64.

39 | For the brief criticism regarding the 'fruitless' opposition of these two methods in the Hungarian scholarly literature, see: Szabó, 2005, pp. 177-178.

40 | Among the Hungarian scholars, István Szászy was the one who, besides staying at the duplexinterpretatio on the surface, used not only Savigny's methods but also the views of Interessenjurisprudenz and Wertungsjurisprudenz. Hence, besides the 'grammatical explanation', he distinguished and recognised the 'logical explanation in narrow sense' as the part of the 'logical explanation' (i.e. the use of the rules of the formal logic in the course of the interpretation and, furthermore, he also mentioned four particular types thereof by names); the 'systematic explanation'; the 'historical explanation' (by which he meant the interpretation of legal regulations according to conclusions from the examination of the legislative history); and the 'evaluative explanation' which 'starts from the premise that the legal regulation tries to reach fair results through meaningful objectives' (Szászy, 1947, vol. I, p.127), namely which contains both the teleological and the substantive elements of the interpretation. It meant that he, as the first among Hungarian scholars, enumerated all interpretation methods which had been defined until then even if only as the part of the interpretation method called 'logical'. (Cf.: ibid.) 
its practical use was also recognised and supported by the advocates of two further legal trends, the German 'Free Law School' (Freirechtsschule) and the 'Legal Realism' of the United States, which expressly found law as such in judicial proceedings.

The mentioned categorisation of Savigny being supplemented by teleological interpretation (and by 'evaluative' [substantive] interpretation as the improvement thereof) determined the legal theoretical thinking of interpretation methods for nearly a century and a half, insomuch that most often this classical systematisation serves as a basis for legal hermeneutics even today. It was also true for Imre Szabó (the most important representative of the Hungarian legal literature of state socialism), who is known as not only the founder and the most significant representative of the 'official legal theory' but also the most influential Hungarian actor in the science of legal interpretation until today. In his work, he did not (only) rely on the results of Soviet jurisprudence, but (primarily) on Savigny's views. Similar to his great German predecessor, Imre Szabó also distinguished four methods of legal interpretation: grammatical, logical, systematic, and historical interpretation. ${ }^{41} \mathrm{He}$ neglected even the teleological interpretation (accepted as the result of the legal development after Savigny);42 overall, he followed his 'master' in everything (wrapping his ideas, of course, in the Marxist-Leninist ideology to a certain extent). The only important difference between them (besides the mentioned ideological aspects) was that he divided these four methods into two categories and saw a relative caesura, a not too strong but even existing line, between the grammatical and logical interpretations (as methods based only on the text of the statute) on the one hand and the systematic and historical interpretations (as methods using also the relationships beyond the text) on the other hand. ${ }^{43}$

41 | According to the definitions of Imre Szabó, the grammatical interpretation 'analyses and examines the text of the statute in its lexical and syntactical sense' (Szabó, 1960, p. 123), namely 'the linguistic analysis (i.e. the examination of the words and the grammatical structures of the legal regulations) is called grammatical analysis' (Szabó, 1960, p. 127). The logical interpretation, besides the rules of conclusion, 'also includes the application of the formal logic principles, of the basics of thinking and of the rules regarding the concept (e.g. defining the concept), the judgements, the proving, etc.' (Szabó, 1960, p. 161). The systematic interpretation 'examines an item as compared to other legal item, a legal institution, the entire statute, codex, the given branch of law, even the entire legal system; and concludes the content, essence, and meaning of the examined norm from the place of the legal item and from its comparison, in the said manner, with other elements of the legal regulation' (Szabó, 1960, p. 171). Finally, in the course of historical interpretation the legal regulation 'has to be examined in historical context going beyond law' (Szabó,1960, p. 200) which also includes occasio legis, i.e. the 'occasion' of the statute (i.e. the concrete event or situation that evoked the need for law-making), the ratio legis, the 'meaning' of the statute and, the fact 'how the content of the legal regulation » has developed «, has enriched since its creation' (Szabó, 1960, p. 223).

42 | Imre Szabó says that the purpose of the legal regulation to be established by teleological interpretation is the part of the legislator's will to be determined by historical interpretation; hence, 'beside historical element, there is no need for separate teleological interpretation' (Szabó, 1960, p. 231).

43 |'The grammatical and logical ... interpretation ... actually examine only the legal regulation itself being isolated from other legal regulations and taken out from the given branch of law and legal system and, finally, kept away from the social contexts. ... after [the] grammatical and logical interpretation, there is a certain caesura and beyond this line, there is the examination of the wider context ... of the legal regulation, the analysis of its place in the legal system and its social relations. Hence, beside the first degree ... of the interpretation (when the grammatical and the logical elements of interpretation are used), we must talk about a second degree which is higher 


\section{Attempts to surpass the 'Canon'}

Due to the development of jurisprudence and the recent results of legal practice, the gradual disintegration and expansion-with other methods-of the traditional interpretation canon of Savigny began in the second part of the twentieth century, primarily in the German-speaking world. In his five-volume large methodological summarising work ${ }^{44}$, Fikentscher took the four plus one division as a basis and completed it only with one method in the middle of the 1970s. Overall, Fikentscher deviated from traditional canon in two ways: on the one hand, he considered the logical and systematic interpretation as a unified coherent interpretation method instead of being two independent methods and, on the other hand, he recognised-similar to others-the evaluative interpretation but only as a tool for controlling the practical correctness of the meaning established on the basis of other methods. Therefore, the following were the methods of 'the Canon', according to him: interpretation on the basis of the text, i.e. literal interpretation ('Auslegung nach dem Wortlaut') as the necessary starting point of all legal interpretations; logical and systematic interpretation ('Auslegung nach Logik und System') in which logic does not principally mean the application of formal logic but-similar to the concept of the 'system' - the consideration of the legal context of the legal norm; historical interpretation ('historische Auslegung') as the use of the legislative history of the concrete norm to establish the intended meaning of the text of the norm; teleological interpretation or 'interpretation according to purpose' ('teleologische Auslegung', 'Auslegung nach dem Zweck'); and 'interpretation' on the basis of the 'value of the result' ('der Wert des Ergebnisses') which, contrary to the other methods, is not a 'self-righteous' method ${ }^{45}$ but merely a subsequent tool to control the meaning established by other methods. ${ }^{46}$

However, the works from the 1980s and 1990s mostly surpassed the traditional division of four plus one and recognised the existence of further recent methods. However, some of them, such as Potacs, gave up the traditional canon only theoretically and in name; since he used a completely different classification than his predecessors, it was incidental and did not constitute a coherent system; therefore, others did not follow this classification later ${ }^{47} \mathrm{He}$ said that interpretation had two main types: semantic and pragmatic interpretation ('semantische Interpretation' and 'pragmatische Interpretation'). The former includes the interpretation according to the clear meaning of the words (klarer Wortsinn), the interpretation based on the relations of the text of the legal norm (actually the systematic interpretation), the interpretation according to the legislative purpose,

than the first one.' (Szabó, 1960, p. 168; - note in the original - T.J.Z.) At the same time, Imre Szabó (similar to Savigny) emphasises that though 'there is a certain succession in the application of these methodological elements but it does not mean that any or some of these elements would be suitable to establish alone the content of the legal regulation, namely that the following element could be applied only if the previous one did not lead to result. Only the entire method can lead to result.' (Szabó, 1960, p. 233.)

44 | Fikentscher, 1975-1977.

45 I This method came from Ludwig Enneccerus and Hans Carl Nipperdey so as to amend, correct, or substitute teleological interpretation; hence, the latter two methods is to be considered as a single unit.

46 | Cf.: Fikentscher, vol. III, 1975, pp. 668-681.

47 | See: Potacs, 1994. 
and the historical interpretation. The latter includes (basically without the determination of thorough systematic relations) argumentum a contrario (Umkehrschluß); analogy; argumentum a fortiori (argumentum a minori ad maius, argumentum a maiori ad minus); interpretation according to general principles (including fundamental rights); reduction techniques ('Reduktionen') just as restrictive, extensive and corrective interpretation (the last three are actually not interpretation methods but the results of interpretation); and other possible methods as part of the latter ones e.g. the principle of implied powers. ${ }^{48}$

Wolfgang Gast, however, distinguished further techniques in addition to the four 'classical' methods of interpretation (literal, systematic, historical, and teleological interpretation) ${ }^{49}$ being the 'accessories of the traditional rhetorical toolbar' (which, as we can see, do not cover the formal logical methods). Thus, for example, he emphasised the role of formal logic in the course of interpretation, but only to the extent necessary for resolving the real controversies of the text, i.e. to avoid tautological argumentation (hence, this method of Gast may actually be used merely as a 'negative' tool grounding the exclusion or the rejection of certain interpretation results instead of being a 'positive' tool supporting the establishment of a certain meaning). ${ }^{50}$ Furthermore, he classified the following as independent methods: i) the examination of the impact history of the text of legal regulations to be interpreted (including, in particular, the interpretation according to the meaning which is attributed to the texts of the norms by the particular judicial decisions and the judicial case law as a whole in the course of their actual, practical application, i.e. the meaning with which the law-appliers incorporate certain norms into their practice); 51 ii) the opinion of authorities (e.g. commentaries added to the legal regulations to be interpreted or the books and scientific works of authors being considered by the lawyers as authentic in the given professional topic);52 iii) 'legal ethical reservations', which mean the conception of righteousness of the person who interprets the text (typically of the judge who wants to decide the case somehow) and its maxims, the opposing meaning of which the judge does not want to use in relation to the given written legal norm and which, therefore, can be applied only subsequently, in the course of selecting from the other possible meanings (this way, similar to the formal logical aspects, this can also be considered merely as a 'negative' method); ${ }^{53}$ and finally, iv) the 'interpretation according to purposes' being legitimate only in certain circumstances. ${ }^{54}$

48 | As we can see, these are systematic and logical arguments; there is, therefore, no ground for differentiating them as 'practical interpretation' from the systematic interpretation being part of 'semantic interpretation'.

49 | He mentions literal interpretation ('Auslegung nach dem Wortsinn') also as grammatical and grammatical-literal interpretation ('grammatische Auslegung', 'grammatikalisch-lexikalische Auslegung'); systematic ('systematische Auslegung') as logical interpretation (!) or interpretation according to relations ('logische Auslegung', 'Auslegung nach dem Zusammenhang'); historical ('Auslegung nach der Geschichte', 'historische Auslegung') as genetic interpretation ('genetische Auslegung'); and teleological ('teleologische Auslegung') as interpretation according to the (objective) purpose of the statute ('Auslegung nach dem Gesetzzweck'). (Cf.: Gast, 1988, pp. 110-114 and 132-177.) 50 | Cf.: Gast, 1988, pp.128-129.

51 | Also, this method is nothing else but the temporal continuing of historical interpretation covering the analysis of legislative history. (Cf.: Gast, 1988, pp.129-130.)

52 | Actually it means the use of results of jurisprudence in the course of interpretation. (Cf.: Gast, 1988, p. 130.)

53 | Cf.: Gast, 1988, pp. 130-131.

54 | Cf.: Gast, 1988, pp. 131-132. 
He also recognised argumentum a contrario and analogy, argumentum a fortiori and argumentum ad absurdum, i.e. the main logical maxims, ${ }^{55}$ not as interpretation methods but only as rhetorical tools. ${ }^{56}$

Finally, it is worth mentioning the theory of Franz Bydlinski among contemporary authors. Regarding the interpretation methods, he insisted on the traditional four plus one canon only formally and, in terms of content, he exceeded it; further, he recognised reasoning funds, which he did not call as 'methods of interpretation', but by the schematisation thereof, he anticipated the ideas of the Bielefelder Kreis (see later). Among the interpretation techniques called 'methods of interpretation', Bydlinski differentiated literal (grammatical), ${ }^{57}$ systematic-logical, ${ }^{58}$ historical (according to the intention of law-maker), ${ }^{59}$ and objective-teleological interpretation ${ }^{60}$ but he divided the last one into five further subcategories: teleological-systematic interpretation ${ }^{61}$ as the interpretation method for determining the objective meaning (independent from the legislator) of the statute (ratio legis); constitution-compliant interpretation (interpretation consistent with the constitution); ${ }^{62}$ argumentum ad absurdum; ${ }^{63}$ interpretation according to the 'nature of the thing' ('Natur der Sache') ${ }^{64}$, which may provide assistance on how to interpret certain obvious and self-evident life relations even with a content opposing the meaning determined by some other methods or may serve as a reference base; and finally, comparative law arguments ${ }^{65}$ in the course of which concrete foreign legal rules or legal solutions generally applied in other (mainly similar or the most advanced) legal systems can be used for interpretation of domestic law. Furthermore, Bydlinski also analysed techniques which he did not call 'legal interpretation methods', but which, regarding their functions, are close to them even according to him. Hence, he also recognised the principle 'lex specialis derogat legi generali' 66 being intended to resolve the (apparent) contradictions of positive law; regarding 'supplementary legal development' among the procedures being able to fill the 'statutory gaps', he specified both types of analogical inference (statutory and legal analogy) and the inverse thereof, the technique of 'teleological reduction' or 'restriction', and the principles a contrario and a fortiori (Umkehrschluß and Größenschluss) together with the involvement of universal ('natural') legal principles into interpretation; finally, he also mentioned the application of law and 'legal thinking' in accordance with precedents and the judicial practice.

55 | Analogy is, of course, not one of the logical maxims.

56 | See the delineation of their content later.

57 | Cf.: Bydlinski, 1982, pp. 437-442.

58 | Cf.: Bydlinski, 1982, pp. 442-448.

59 | Cf.: Bydlinski, 1982, pp. 449-153.

60 | In Bydlinsksi's own words, 'wörtliche Auslegung' ('grammatische Auslegung'); 'systematischlogische Auslegung'; 'historische Auslegung' ('Auslegung nach der Absicht des Gesetzgebers'); 'objektiv-teleologische Auslegung').

61 | Cf.: Bydlinski, 1982, pp. 453-455.

62 | Cf.: Bydlinski, 1982, pp. 455-457.

63 | Cf.: Bydlinski, 1982, pp. 457-459.

64 | Cf.: Bydlinski, 1982, pp. 459-461.

65 | Cf.: Bydlinski, 1982, pp. 461-463.

66 | Cf.: Bydlinski, 1982, p. 465. 


\section{Paradigm shift in legal methodology: Results of the Bielefelder Kreis}

Due to the change in judicial practice, the development of international comparative law, the learning of judicial practices of other legal systems, and the use of new interpretation techniques, ${ }^{67}$ it became, as we have seen, increasingly untenable to reduce the interpretation methods to the traditional four or five types. Moreover, in the scholarly literature, it has become widespread that the courts apply methods other than the classical ones to establish the meaning of an ambiguous legal regulation. Partly purposefully for the sake of understanding and systematising these methods but generally to establish the basic principles and features determining the actual operation of jurisprudential practice of different legal systems belonging to the European culture, an international group of legal scholars, Bielefelder Kreis ${ }^{68}$ was established in the 1980s, which decided to

67 | As a consequence, rules of interpretation have appeared in some international documents and in the domestic law of some countries, which (inter alia) are based on the results of the theoretical developments presented above to help the relevant judicial body in the interpretation of the applicable legal provisions. The most famous of these is, probably, the canon of interpretation of the Vienna Convention on Law of Treaties, the use of which has been made compulsory by, e.g. the European Court of Human Rights in the 1975 Golder case (Golder v the United Kingdom, application no. 4451/70, 21 February 1975). Among 'General rules of interpretation', Article 31 declares that 'A treaty shall be interpreted in good faith in accordance with the ordinary meaning to be given to the terms of the treaty in their context and in the light of its object and purpose'. Under the title 'Supplementary means of interpretation', Article 32 defines, not exhaustively, other methods and sources: 'Recourse may be had to supplementary means of interpretation, including the preparatory work of the treaty and the circumstances of its conclusion, in order to confirm the meaning resulting from the application of article 31, or to determine the meaning when the interpretation according to article 31: (a) Leaves the meaning ambiguous or obscure; or (b) Leads to a result which is manifestly absurd or unreasonable.' Finally, according to Article 33 (Interpretation of treaties authenticated in two or more languages):' 1 . When a treaty has been authenticated in two or more languages, the text is equally authoritative in each language, unless the treaty provides or the parties agree that, in case of divergence, a particular text shall prevail.' (etc.) This is, hence, as mentioned above, also applicable, e.g. to the interpretation of the European Convention on Human Rights.

68 I The prelude of the group's formation was the IVR World Congress in Philosophy of Law and Social Philosophy in Helsinki in 1983 where some participants proposed to map the condition of the contemporary judicial law application. In 1986, following three years of ad hoc research, it became serious when these legal scholars decided to carry out a systematic research regarding certain aspects of adjudicating so that participants examine the operating features of the justice systems in their own country. (Cf.: MacCormick and Summers, 1991, pp. XI-XIII.) Finally, the legal scholars of nine countries performed the empirical study of their countries in this respect (until 1990). During the selection of the countries (or the legal scholars thereof), it was also taken into account that the sample must include all important legal systems and one representative of each type of different legal systems (belonging to the European culture). Accordingly, the judicial practice, including the examination of arguments applied during interpretation of legal norms, of the higher courts of Argentina, France, Finland, Germany, Italy, Poland, Sweden, the United Kingdom, and the United States were examined. (MacCormick and Summers, 1991, pp. 1-2.) The broad sense of the concept of 'higher courts' was applied including not only the supreme court but also all fora entitled to make decision in a certain case at the highest level and courts of appeal, the decisions of which are not 
conduct-under the guidance and direction of Robert Summers-a remarkably detailed international research covering all substantial segments of adjudication which enables to determine, inter alia, the interpretation methods and reasoning techniques applied by the courts of countries belonging to the European culture in the course of resolving a legal interpretation problem. The results of this survey were published in 1991; according to this, a total of eleven arguments exist which-with larger or smaller regularity-are taken into consideration in the course of interpreting legal regulations by the supreme courts of the countries examined in the research, i.e. on the basis of which the real meaning of the statute(s) being unclear in the certain case can be explored.

These eleven methods were classified into four main categories based on the context in which we interpret the text of legal norms. ${ }^{69}$ It can be a simple linguistic context in case of which a general or specific grammatical meaning of the text is established; the context of the social-legal structure when we determine the meaning of the legal regulation based on the legal environment or the operating legal practice which surrounds the given positive legal provisions; the context of the purpose of the legal regulation which (regarding the consequences of law application) presents the judge with an evaluative choice between the linguistically equally correct meanings in the course of determining the meaning of the ambiguous legal norm relevant to the given case; and the context of the intention of the legislator which forces the law-applier to take the explicit or implicit intention (namely the subjective will which led the legislator to create the given legal provision) into account. On the basis thereof, the researchers led by Summers classified the eleven arguments used or usable by courts in the course of legal interpretation in four main categories: ${ }^{70}$ the first category (I) is formed by the 'linguistic arguments', the second (II) by the 'systemic arguments', the third (III) covers the 'teleological/evaluative arguments' while the fourth one (IV) contains the 'argument from intention' which belongs to none of the previous three categories, i.e. a 'transcategorical' argument over the three other ones.

Two specific methods (1-2) belong to the linguistic arguments (interpretation methods $)^{71}$ forming category I: the argument from ordinary meaning (1) and the argument from technical meaning (2). When applying the first one, we try to establish the 'obvious meaning' that would be attributed-based on the everyday meaning of the ordinary words-to the norm in question by a person speaking the given language on an ordinary level. If the everyday meaning would allow interpretations leading to several results, the most generally accepted and the most obvious must be applied; if it is not

the final one; however, constitutional courts and, in general, the interpretation of the constitution were excluded from this research since these, according to the researchers, work with logic and arguments different from the ones used by the ordinary courts in the course of legal (norm) interpretation (MacCormick and Summers, 1991, pp. 13-14). (By 'statutes', they meant not only statutes but all normative actions which were created by a public body entitled to make abstract norms mandatory for citizens and applicable during judicial law application, i.e. any elements of the law (statutes, decrees, or other positive legal norms). (MacCormick and Summers, 1991, pp. 10-11 and 25.) Finally, it has to be mentioned that the concept of 'interpretation', as the subject of the result, was understood in sensu stricto, and meant the determination of the actual meaning of ambiguous legal norms (MacCormick and Summers, 1991, pp. 12-13).

69 | Cf.: MacCormick and Summers, 1991, p. 26.

70 | Cf.: MacCormick and Summers, 1991, pp. 21 and 512-515.

71 I I use the terms 'argument' and 'interpretation method' as synonyms below. 
possible to decide, the given provision must be understood with the meaning which, as a result of the use of other methods, is probably considered to be the most appropriate in the wider context. ${ }^{72}$ On the contrary, the latter argument uses a special technical meaning instead of ordinary one; in this case, we attribute a meaning to a given word or expression which meaning would be attributed also by a person experienced in the particular (legal or other) profession involved. Most often, this technical meaning is the legal professional meaning, but it can happen that a legal norm regulating a particular field uses the technical words of that field; hence, the interpretation must also be conducted in light of these (not legal) termini technici. ${ }^{73}$

According to Summers et al., six further methods of interpretation (3-8) were determined in the range of the 'systemic arguments' belonging to category II $^{74}$ : the argument from contextual-harmonization (3), the 'argument from precedent' (4), the argument from analogy (5), the logical-conceptual argument (6), the argument from general principles of law (7) and the 'argument from history' (8). In the case of arguments from contextualharmonization, the meaning of a given legal provision is established on the basis of its position in the legal system. During this, we can consider other parts of the section where the legal provision to be interpreted was regulated, further relevant sections of the same legal regulation, and other pertinent legal norms which can interpret the legal norm in question. ${ }^{75,76} \mathrm{As}$ the quotation marks (not used below) also indicate, the 'argument from precedent' does not merely mean the consideration of precedents in the course of interpretation, which is typical for common law systems, but, in general, the statutory interpretation achieved by the reasoning of previous court decisions. Often, these do not use a concrete previous relevant judicial decision to explore the true meaning of the legal norm with obscure text but a set of such decisions; i.e. they do not refer (only) to the 'precedents' in the strictest sense but (also) to the entire case law regarding the legal provision in question. Regardless, the substance of the argument is the same in both cases: the courts interpret the given norm like the other courts did when they decided previous cases with similar facts, i.e. the adjudicating bodies making decisions in the similar cases use the previous judicial decisions as a sample for deciding the given legal interpretation problem. ${ }^{77}$

In the case of argument from analogy (which Summers et al. called 'arguments based on statutory analogies'78, but was meant to be a systematic-contextual based extensive argumentation as the result of interpretation ${ }^{79}$, we interpret a (an existing) legal norm in light of

72 | Cf.: MacCormick and Summers, 1991, pp. 464 and 512-513.

73 | Cf.: MacCormick and Summers, 1991, pp. 464 and 513.

74 | Arguments other than linguistic (also the systematic ones) can actually have three functions: they can confirm the everyday or technical (namely literal) meaning of the words used by the legal rule; or can underpin the accuracy of the application of another meaning against this grammatical meaning (i.e. can 'deteriorate' literal meaning) or clarify the real meaning of the words, expressions, and sentences having obscure linguistic-grammatical meaning. (Cf.: MacCormick and Summers, 1991, p. 465.)

75 | As we can see, it is actually identical to the systematic interpretation in the classification of Savigny. 76 | Cf.: MacCormick and Summers, 1991, pp. 464-465, 466-467 and 513.

77 | Cf.: MacCormick and Summers, 1991, pp. 467. 487-490 and 513.

78 | Cf.: MacCormick and Summers, 1991, p. 465.

79 | Accordingly, this argument actually covers all others because any other argument can be used to determine the 'significant' similarity in the real meaning of the two statutory provisions. 
a relevant legal norm regulating another but similar subject matter ${ }^{80}$ so that the meaning of the latter would also cover the case regulated by the former norm. ${ }^{8182}$ In the course of logical-conceptual argumentation, we apply the meaning of a given legal concept generally accepted and elaborated by jurisprudence in the given system in all cases when that legal concept appears in a legal regulation. ${ }^{83}$ Hence, through the operation of interpretation, we strive towards conceptual coherence in the legal system and do not use formal logical arguments to establish the implied but not explicit meaning of the text (that we would do by using interpretatio logica defined by Savigny). In the case of argument from general principles of law, according to the Bielefelder Kreis, to establish the 'correct' meaning of a certain provision, we use substantive moral principles which serve as (partial) basis for previous court decisions and enable to make 'correct' interpretative decisions, or general principles determining the entire legal system (and usually recognised also on constitutional level), or widely used rules of a branch of law which have the nature of general clauses. ${ }^{84}$ Finally, in the course of the 'customary law' interpretation (called 'historical' by Summers et al.), the meaning of the legal norm in question can be determined on the grounds that, regarding the circumstances of the process of legislation, what purpose and function the created legal regulation has; ${ }^{85}$ and what meaning or what understanding (solidified and accepted by the lawyers) has been subsequently attached to this legal provision during the long years of its use (including the meaning attributed by courts, the conventional doctrinal understanding, and the fact that the meaning created that way was appropriate also for the legislator; otherwise, it would have changed the text of the norm in question). ${ }^{86}$

The third category contains the teleological and evaluative arguments, with a total of two arguments (9-10): the argument from (statutory) purpose (9) and the argument from substantive reasons (10). The former orders to apply the one from the potential meanings (determinable by other methods) of the legal norm to be interpreted which is oriented mostly to the goal, social purpose, and function of the given norm and (also regarding the expectable factual consequences) serves them the most. ${ }^{87,88}$ The latter, in the course of legal interpretation, requires the direct use of values which have or had influence on the legal provision in question and, generally, on the formation and structure of the legal system.

80 |'The argument from analogy: the governing idea here is that if a statutory provision is significantly analogous with similar provisions of other statutes, or a code, or other part of the code in which it appears, then [...] it may properly be interpreted so as to secure similarity of sense with the analogous provisions either considered in themselves or considered in the light of prior judicial interpretation of them.' (Cf.: MacCormick and Summers, 1991, pp. 513-514.)

81 | Cf.: MacCormick and Summers, 1991, pp. 467 and 513-514.

82 In this sense, it is true that, to a certain extent, this kind of argument is accepted and used in every examined country (which would hardly be defensible in the light of the real meaning of analogy). (Cf.: MacCormick and Summers, 1991, 467.)

83 | Cf.: MacCormick and Summers, 1991, pp. 465, 467, and 514.

84 | Cf.: MacCormick and Summers, 1991, pp. 465, 467-469, and 514.

85 | However, the placement of this argument is confusing because, as we will see, it also belongs to the interpretation number 10 the argument from (statutory) purpose.

86 | Cf.: MacCormick and Summers, 1991, pp. 465, 469, and 514. [As we can see, it is a considerably diffuse, diverse argument which also combines the elements of teleological, historical (based on the determination of the legislator's intention), substantive, legal conceptual, and other arguments.] 87 | Cf.: MacCormick and Summers, 1991, pp. 469 and 514.

88 This method is actually nothing else but the teleological interpretation formed during the doctrinal development after Savigny's classification of four categories. 
They may include certain direct moral, political, economic, or social considerations, namely aspects which serve as the theoretical basis of a given legal norm or the entire legal system. ${ }^{89}$ Finally, the fourth main category is the argument from intention (11), which itself is-as a transcategorial technique over the arguments of the other categories-the eleventh interpretation method. It seeks the will of the legislator, namely, what it wanted to achieve when creating the norm with such text. It is considered to be 'above' the arguments of other categories because it covers all of them. When applying this method, the judge has to ask what meaning the legislator wanted to attribute to the words, expressions included in the statute, the legal context it wanted to place the provision in question into, whether it wanted to rely on the prior results of court interpretation, whether it wished if the law created by it was interpreted and applied analogously, and so on. ${ }^{90}$

The Bielefelder Kreis says that beyond these eleven methods, there are a few more possible arguments which are, however, rarely used in practice; these are the interpretation according to the meaning attributed to the statute by the implementing body, the legal dogmatic interpretation, and the interpretation based on hypothetical cases. ${ }^{91}$ In the case of the first one, the court attributes to the statute a meaning which, in the frames of an expressly interpretative provision, was also attributed by an administrative authority ordered to apply the given statute (either in an abstract way or regarding a particular case but necessarily as a matter of principle). In the course of the legal dogmatic interpretation, we use concrete jurisprudential works, commentaries, and essays of particular legal scholars to determine the actual (legal) meaning of the statute. ${ }^{22}$ Finally, in the case of interpretation based on hypothetical cases, the judges consider what underlying effect the given decision would have in cases which, although have not occurred during law application, may occur in the future; in such cases, the task of the law-applier is to make a decision (i.e. to attribute a meaning to the norm in question), the subsidiary consequences of which will also be acceptable in these further possible cases. ${ }^{93}$

\section{Impact of the Bielefelder Kreis: Attempts at classification of methodology in the $21^{\text {st }}$ century ${ }^{94}$}

The methodological classification of the Bielefelder Kreis provided the development of argumentation theory with a significant impetus. It had such a huge impact that, from the 1990s, this classification has been the standard of methods of interpretation and

89 | Cf.: MacCormick and Summers, 1991, pp. 469-470 and 514-515.

90 | Cf.: MacCormick and Summers, 1991, pp. 21, 470-471, 515, 522-525.

91 | Cf.: MacCormick and Summers, 1991, pp. 473-474.

92 | This method shows many similarities to the interpretation based on the legal technical meaning of the words (delineated as method number 2 in the classification by Summers).

93 | The Bielefelder Kreis formulated here the legal logical maxim of argumentum ad absurdum. 94 | As the title of the present paper itself suggests, we cannot undertake a full or even comprehensive presentation here. We have chosen only authors who have an explicit methodological classification, i.e., who have not simply addressed methodological issues, but have sought to provide an explicit categorisation of methods of interpretation. Here, we have therefore ignored works dealing with general theoretical issues of legal interpretation or with normative approaches to certain methods, leaving their analysis to other papers dealing specifically with the latter issues. 
argumentation which the legal academics want to either use without changing (mainly during their legal sociological research) or exceed methodologically or, perhaps, complete or specify. (Sometimes, its use in favour of legal sociological examination and the purpose for development of argumentation theory are present at the same time in the same research.) Eventually, all studies (even if their methodologies do not exactly match the one used by the Bielefelder Kreis) start from this classification and go back to that. ${ }^{95}$ However, some new methodological classifications must be highlighted from the further development of history of argumentation theory, which proved to be determinativeeither on their own (due to their doctrinal importance) or as the result of their use during the empirical legal sociological research carried out-and also inspired the methodology of the present research.

In his legal sociological study analysing 600 decisions of the Hungarian Supreme Court, Béla Pokol applied a methodological classification differentiating in a total of ten specific arguments ${ }^{96}$ : '1. Interpreting the legal text in view of the meaning of the words in everyday language; 2 . Interpreting the legal text in view of the special/technical meaning of the words, provided that a given word or phrase has such a meaning either in addition to its everyday meaning or has no other than such a meaning; 3 . Contextual interpretation means the type of interpretation of the legal text where the words of each provision are construed in compliance with the meaning attributed to them when fitted in the entirety of the law or a complete body of related laws; 4 . Interpreting the legal text on the basis of law logistics maxims; 5 . Interpreting the legal text through analogy; 6 . Interpreting the legal text on the grounds of precedents set at the time of previously enforcing the given law; 7. Interpretation on the grounds of legal dogmas and doctrines; 8 . Interpreting the legal text in the light of implied ethical values of law or certain branches of law; 9. Interpreting the legal text in the light of the aims of the given statute; 10. Interpreting the legal text on the grounds of the will of the legislator.' ${ }^{\prime 7}$

Similar to Summers et al., Pokol followed (mostly) the division of the Bielefelder Kreis when he studied the practice of statutory interpretation. Later, András Jakab laid down his own methodology (mainly based also on that of Summers et al.) in the course of explicitly studying constitutional reasoning. Jakab presumed, as we have also done above, that argumentation and interpretation are different (he also used the concepts of 'argumentation' and 'reasoning' as synonyms) and considered 'interpretation' as a specific kind of argumentation. ${ }^{98}$ He says, 'Most arguments in constitutional reasoning aim to interpret the constitution', ${ }^{9}$ but there are types of argumentation which do not aim at interpretation but something else. According to him, these include the following three arguments:

95 | We do the same in the course of the present comparative law examination.

96 In his later work in French language, he completed it to eleven arguments, adding the interpretation in light of fundamental constitutional rights and principles (cf.: Pokol, 2007, p. 397); and in his work in Hungarian, he broadened it to twelve arguments also recognising, in addition to interpretation in light of fundamental constitutional rights and principles (cf.: Pokol, 2005, pp. 227-228), the 'interpretation referring to legal principles' (an individual, specific type of interpretation on the grounds of legal dogmas and doctrines) as a new independent method (Pokol, 2005, p. 227).

97| Pokol, 2001, p. 465.

$98 \mid$ '[A]rgumentation [...] is used as synonymous [...] with reasoning. Interpretation [...] means determining the content of a normative text. [...] Consequently, what is traditionally called 'a method of interpretation', is in fact a type of argument used to interpret a text.' (Jakab, 2013, pp. 1219-1220.) 99 | Jakab, 2013, p. 1220. 
the analogies (including, in the broader sense, also the teleological reduction), 100 establishing the (valid) text of the constitution, and arguments about why the text of the constitution should or should not be applied (briefly: arguments on the applicability of the constitution). ${ }^{101}$ In addition to these 'rare exceptions', there are interpretation methods (the majority of arguments) ${ }^{102}$ which can be divided into three argument types (and two more methods outside these ones). The first argument type is the 'ordinary or technical meaning of the words', which is identical to the classification of Summers since it covers the plain meaning of the words and the legal and non-legal professional meaning. ${ }^{103}$ The second argument type is called 'systematic arguments' within which the 'harmonizing arguments'104, 'referring the precedents which interpret the constitution'105, interpretation 'in the light of doctrinal concepts or principles', ${ }^{106}$ and 'linguistic-logical formulae based on silence'107 can be distinguished. The third argument type is the 'evaluating argument'108 to which 'relying on the objective purpose of the norm', ${ }^{109}$ 'relying on the intention of the constitution-maker'110 (also including 'argumentum ad absurdum'), ${ }^{111}$ and the 'substantive arguments' [interpreting the norms in the light of non-legal (e.g. moral) aspects] belong. ${ }^{112}$ Further interpretation methods, which cannot be classified into any of the three groups above, are 'referring to scholarly works'113 and 'arguments from comparative law'.114 The above classification served as the basis of Project CONREASON launched in 2015. ${ }^{115}$

100 | Cf.: Jakab, 2013, p. 1221.

101 | Jakab, 2013, p. 1220.

102 | [T] he vast majority of arguments are interpretive in their nature. (Jakab, 2013, p. 1223.)

103 | Jakab, 2013, pp.1231-1233.

104 It practically corresponds the argument from contextual-harmonization from the categorization of Summers. (Jakab, 2013, pp.1233-1235.)

105 | Jakab, 2013, pp. 1235-1239.

106 | Jakab, 2013, pp. 1239-1240.

107 | Here, Jakab classified not only argumentum a contrario but also argumentum a maiori ad minus, argumentum a minori ad maius, and other maxims (which can be classified to a contrario). (Cf.: Jakab: op. cit., p. 1240.)

108 | According to Jakab, these are the arguments which help 'beyond the legal context' to interpret the (constitutional) norm. (Jakab, 2013, p.1241.)

109 | Jakab, 2013, pp. 1241-1243.

110 | Jakab, 2013, p. 1246. To distinguish it from objective teleological arguments, Jakab calls it 'subjective teleological arguments', which method researches the 'intention' of the entity creating the norm [also including the use of the legislative history ('travaux préparatoires') as source]. Hence it tries to explore its will definitely.

111 | Jakab, 2013, p.1249.

112 | Jakab also says that these can be only exceptionally applied, e.g. 'where no other arguments can help, or other arguments lead to interpretations contradicting one another and one has to choose'. (Jakab, 2013, p. 1250.)

113 | Jakab, 2013, pp. 1251-1252.

114 | Jakab, 2013, pp. 1252-1254.

115 I It had the ambitious aim 'to develop the most comprehensive and most systematic analysis of constitutional reasoning that has ever been produced'. (Jakab, Dyevre and Itzcovich, 2015, p. 3.) For this purpose, in the course of the actual research, the research participants analysed, on the basis of the methodology described, 40-40 (a total of 760) leading cases of the constitutional or supreme courts of sixteen countries, of the European Court of Human Rights, and the Court of Justice of the European Union; and tried to define the contemporary characteristics of the "constitutional reasoning' and the similarities and differences between the certain countries or types of 
Finally, we must mention that, for conducting two different empirical legal sociological studies, the author of the present study has set up two methodological classifications: one for the statutory interpretation and one for the constitutional interpretation. Regarding the statutory interpretation methods and developing the views of Bielefelder Kreis, we have distinguished the following methods: (1.) grammatical interpretation: (1/A.) interpretation in accordance with ordinary meaning, and, within it, (1/A.a.) semantic or (1/A.b.) syntactic interpretation; (1/B.) legal professional (dogmatic) interpretation, and, within it, (1/B.a.) simple conceptual (dogmatic) interpretation, (1/B.b.) interpretation explicitly by principles of statutes or branches of law, (1/B.c.) contextual interpretation in its broad sense ${ }^{116} ;(1 / C$.) interpretation in accordance with the technical terms of other (non-legal) professions. (2.) Contextual interpretation in its narrow sense. (3.) Interpretation in accordance with the former judge-made law. (4.) Interpretation in accordance with other (non-judicial) public authorities in the administration of justice: (4/A.) interpretation as per public authorities' principled decisions; (4/B.) interpretation as per other domestic administrative organs' (e.g. ombudsmen) case decisions and declared opinions; (4/C.) interpretation in conformity with the judgements or sentencing practice of international judicial forums under the scope of their authority. (5) Logical interpretation: (5/A.) argumentum a minori ad maius; (5/B.) argumentum a maiori ad minus; (5/C.) argumentum ad absurdum; (5/D.) argumentum a contrario; (5/E.) argumentum a simili; (5/F.) other logic formulas. (6) Teleological (purposive) interpretation. (7) Historical interpretation (based on the intent of the lawmaker). (8) Interpretation by particular works of jurisprudence or legal literature. (9) Interpretation on the basis of constitutional rights, principles, values, and constitutional court decisions. (10) Interpretation as per international treaties. ${ }^{117}$ (11) Comparative legal interpretation. (12) Interpretation via general principles. (13) Substantive interpretation. (14) Other, legal system-specific methods. ${ }^{118}$

legal systems. The examined fora included the following: the High Court of Australia, the Austrian Constitutional Court, the Supreme Federal Tribunal of Brazil, the Supreme Court of Canada, the Czech Constitutional Court, the French Constitutional Council, the German Federal Constitutional Court, the Hungarian Constitutional Court, the Irish Supreme Court, the Supreme Court of Israel, the Italian Constitutional Court, the Spanish Constitutional Tribunal, the Constitutional Court of South Africa, the Constitutional Court of Taiwan, the Supreme Court of the United Kingdom, and the Supreme Court of the United States. (Cf.: Jakab, Dyevre and Itzcovich, 2017b, p. 26.) We cannot undertake to delineate the results of this comparative legal research. For that, see: Jakab, Dyevre and Itzcovich, 2017b, pp. 761-797.

116 | The expression of 'contextual interpretation' has a narrower and broader meaning. In its broader sense, there are cases belonging to it when a court finds the meaning of a given provision (either in an act or in a decree) on the score of (i.e. in accordance with or in consideration of) other specific provisions of either the same statute or other statutes. Regarding its narrower meaning, I will speak about 'contextual interpretation' in cases when one tries to define the meaning of a legal norm by virtue of the designation that derives purely from the emplacement of the provision to be interpreted in the system of the legal norms (i.e. where one can find that provision, namely, in which statute, part, chapter, subchapter, title, article, etc.), without setting it against other statutory provisions.

117 In respect to this method, only those international treaties etc. have relevance which had been incorporated into the domestic legal system, i.e., which are ratified and promulgated.

118 | As for the Hungarian law, such method is, for example, the interpretation via European Union legal rules. As for other legal systems, e.g., in the component states of a federation, such methods can be the interpretation by federal rules, federal judge-made law, the legislative history of similar subjected federal laws, etc. 
The methods of constitutional reasoning, including those of constitutional interpretation, have several similarities with methods of ordinary legal reasoning, but, compared to them, they are-to a lesser but important extent-special in certain aspects. ${ }^{119}$ Therefore, it is reasonable to talk about independent constitutional interpretation separated from ordinary statutory interpretation and about constitutional reasoning (including both the methods and other sources). According to our classification, these are as follows: 1. grammatical (textual) interpretation: 1/A. interpretation based on ordinary meaning: a) semantic interpretation, b) syntactic interpretation; 1/B. legal professional (dogmatic) interpretation: a) simple conceptual dogmatic interpretation (regarding either constitutional or other branches of law), b) interpretation on the basis of legal principles of statutes or branches of law; $1 / C$. other professional interpretation (in accordance with a non-legal technical meaning). 2. logical (linguistic-logical) arguments: $2 / A$. argumentum a minore ad maius; $2 / B$. argumentum a maiore ad minus; $2 / C$. argumentum ad absurdum; $2 / D$. argumentum a contrario/arguments from silence; $2 / E$. argumentum a simili, including analogy, 2/F. interpretation according to the other logical maxims. 3. domestic systemic arguments (systemic or harmonizing arguments): 3/A. contextual interpretation: a) in a narrow sense, b) in a broad sense (including the so-called 'derogatory formulae': lex superior derogat legi inferiori, lex specialis derogat legi generali, lex posterior derogat legi priori); $3 / B$. interpretation of constitutional norms based on domestic statutory law (acts, decrees); $3 / C$. interpretation of the fundamental rights on the basis of jurisprudence of the constitutional court: a) references to specific previous decisions of the constitutional court (as 'precedents'), b) reference to the 'practice' of the constitutional court, c) references to abstract norms formed by the constitutional court; $3 / D$. interpretation of the fundamental rights on the basis of jurisprudence of ordinary courts: a) interpretation referring to the practice of ordinary courts, b) interpretation referring to individual court decisions, c) interpretation referring to abstract judicial norms; $3 / E$. interpretation of fundamental rights based on normative acts of other domestic state organs 4 . external systemic and comparative law arguments: 4/A. interpretation of fundamental rights based on international treaties; 4/B. interpretation of fundamental rights based on individual case decisions or jurisprudence of international fora; $4 / C$. comparative law arguments: a) references to concrete norms of a particular foreign legal system (its constitution, statutes, decrees), b) references to decisions of the constitutional court or the ordinary court of a particular foreign legal system, c) general references to the 'European practice', the 'principles followed by democratic countries', and similar non-specific justificatory principles; $4 / D$. other external sources of interpretation (e.g. customary international law, ius cogens, etc.). 5. teleological/objective teleological interpretation (based on the objective and social purpose of the legislation). 6. historical/subjective teleological interpretation (based on the intention of the legislator): 6/A. interpretation based on ministerial/proposer justification; 6/B. interpretation based on draft materials; $6 / C$. interpretation referring, in general, to the 'intention, will etc. of the constitution-maker; $6 / D$. other interpretations based on the circumstances of making or modifying/amending the constitution or the constitutional provision (fundamental right) in question. 7. interpretation based on jurisprudence (references to scholarly works).

119 | That is why, for example, the research of Bielefelder Kreis delimited statutory interpretation from constitutional interpretation which (mostly in the USA) 'has long been deemed a topic quite distinct from general statutory interpretation'. (MacCormick and Summers, 1991, p. 11.) 


\section{8. interpretation in the light of general legal principles(not expressed in statutes) 9 . substantive interpretation, directly referring to generally accepted non-legal values.}

\section{Conclusion}

No categorisation of legal interpretation methods is better than any other; therefore, classification must be adjusted to the purpose of the research. Thus, the specification of the methodology cannot be arbitrary: the delimitation of certain methods and the determination of their scope must always take place for conducting a certain research (in a meaningful manner). However, researches regarding theoretical history prove that this is not given in advance but developed over time, and became recognised only from the end of the twentieth century; however, today it is the substance of methodological thinking. This is how the philosophy of law and the legal sociology, the theory and the practice gradually become inseparable, and how theoretical thinking becomes useful for the legal practice.

The present study could not delineate all methodological classifications significant in the theoretical history. Its aim was to provide an overview of the main development stages of decisive methodological thinking in the theoretical history. The overall conclusion of the study is that the chiselling of the methodology and the fact that methodological thinking is becoming more and more practice-oriented indicates a clearly visible development trend which, nowadays, is important not only for the theory but also for the practice, and the importance of the method and its (direct) availability in legal sociological research will surely increase in the near future compared to the current situation. 


\section{Bibliography}

Angyal, P. (1909) A magyar büntetöjog tankönyve [Textbook of the Hungarian Criminal Law]. Budapest: Athenaeum.

Bessenyő, A. (2003) Római magánjog [Roman Private Law]. Budapest-Pécs: Dialóg Campus.

Bydlinski, F. (1982) Juristische Methodenlehre und Rechtsbegriff. Wien - New York: Springer-Verlag.

Devenish, G. E. (1991) 'The Nature of Legal Reasoning Involved in the Interpretation of Statutes', Stellenbosch Law Review, 2(2), pp. 224-241.

| Fikentscher, W. (1975) Methoden des Rechts. Band III. Tübingen: J. C. B. Mohr.

| Fikentscher, W. (1975-1977) Methoden des Rechts. Tübingen: J. C. B. Mohr.

Finkey, F. (1914) A magyar büntetöjog tankönyve [Textbook of the Hungarian Criminal Law]. Budapest: Grill Károly Könyvkiadóvállalata.

Földi, A., Hamza, G. (1996) A római jog története és institúciói [History and Institutions of Roman Law]. Budapest: Nemzeti Tankönyvkiadó.

Frank, I. (1845) A közigazság törvénye Magyarhonban. I. rész [The Statute of Public Justice in Hungary. Part I]. Buda: Magyar Királyi Egyetem.

Gast, W. (1988) Juristische Rhetorik: Auslegung, Begründung, Subsumtion. Heidelberg: R. v. Decker, G. Schenk.

Gebauer, M. (2000) 'Uniform law, general principles and autonomous interpretation', Uniform Law Review, 5(4), pp. 683-706. [online]. Available at: https://doi.org/10.1093/ ulr/5.4.683 (Accessed: 10 September 2021).

Grosschmid, B. (1905) Magánjogi előadások: Jogszabálytan [Private Law Presentations: Legislation]. Budapest: Athenaeum.

I Heck, P. (1914) Gesetzauslegung und Interessenjurisprudenz. Tübingen: Verlag von Mohr. Hoecke, M. Van, Ost, F. (1998) 'Legal doctrine in crisis: Towards a European legal science', Legal Studies, 18(2), pp. 197-215. [online]. Available at: https://doi.org/10.1111/ j.1748-121X.1998.tb00013.x (Accessed: 10 September 2021).

| Holdsworth, W. (1938) A History of English Law. Volume XII. London: Methuen \& Co. Ltd.

I Holland, T. E. (1916) The Elements of Jurisprudence. Oxford, Clarendon Press.

Jakab, A., Dyevre, A., Itzcovich, G. (2015) 'CONREASON - The Comparative Constitutional Reasoning Project. Methodological Dilemmas and Project Design', MTA Law Working Papers (Hungarian Academy of Sciences), 2015/9. pp. 1-24. [online] Available at: https://jog.tk.hu/mtalwp/conreason-the-comparative-constitutionalreasoning-project-methodological-dilemmas-and-project-design (Accessed: 10 September 2021). 
Jakab, A., Dyevre, A., Itzcovich, G. (2017a) 'Conclusion' in Jakab, A., Dyevre, A., Itzcovich, G. (eds.) Comparative Constitutional Reasoning. Cambridge: Cambridge University Press, pp. 761-797.

Jakab, A., Dyevre, A., Itzcovich, G. (2017b) 'Introduction: Comparing Constitutional Reasoning with Quantitative and Qualitative Methods' in Jakab, A., Dyevre, A., Itzcovich, G. (eds.) Comparative Constitutional Reasoning. Cambridge: Cambridge University Press, pp.1-35.

Jakab, A. (2013) 'Judicial reasoning in constitutional courts: A European perspective', German Law Journal, 14(8), pp. 1215-1275. [online]. Available at: https://doi.org/10.1017/ S207183220000225X (Accessed: 10 September 2021).

Jhering, R. von (1877) Der Zweck im Recht. Erster Band. Leipzig: Druck und Verlag von Breitkopf \& Härtel.

Kiss, G. (1909) A jogalkalmazás módszeréről [On the Method of Law Enforcement]. Budapest: Athenaeum.

MacCormick, N. D., Summers, R. S. (eds.) (1991) Interpreting Statutes: A Comparative Study. Aldershot: Dartmouth Publishing Company.

MacCormick, N. (1995) 'Argumentation and interpretation in law', Ratio Juris, 6(1), pp. 16-29. / Argumentation, 9(3), pp.467-480. [online]. Available at: https://doi.org/10.1007/ BF00733152 (Accessed: 10 September 2021).

Maine, H. S. (1861) Ancient Law: Its Connection with the Early History of Society, and its Relation to Modern Ideas. London: John Murray.

Pokol, B. (2000) 'Statutory Interpretation and Precedent in Hungary', East European Quarterly, 34(4), pp. 465-488.

| Pokol, B. (2005) Jogelmélet [Legal Theory]. Budapest: Századvég.

Pokol, B. (2007) 'Interprétation et jurisprudence en Hongrie' in Hondius, E. (ed.) Precedent and the Law: Reports to the XVIIth Congress / International Academy of Comparative Law, Utrecht, 16-22 July 2006. Brussels, Bruylant, pp. 397-422.

Potacs, M. (1994) Auslegung im Öffentlichen Recht. Baden-Baden: Nomos Verlaggesellschaft.

| Regelsberger, F. (1893) Pandekten. Erster Band. Leipzig: Verlag von Duncker \& Humblot.

| Savigny, F. C.von (1840) System des heutigen Römischen Rechts. Erster Band. Berlin: Veit.

Scallen, E. A. (1995) 'Classical Rhetoric, Practical Reasoning, and the Law of Evidence', American University Law Review, 44(5), pp. 1717-1816.

Szabó, I. (1960) A jogszabályok értelmezése [Interpretation of Legal Regulations]. Budapest: Közgazdasági és Jogi Könyvkiadó.

Szabó, M. (2005) Ars iuris: A jogdogmatika alapjai [Ars Iuris: Basics of the Legal Dogmatic]. Miskolc: Bíbor Kiadó. 
Szászy, I. (1947) A magyar magánjog általános része különös tekintettel a külföldi magánjogi rendszerekre. I. kötet [General Part of the Hungarian Private Law with Particular Reference to the Foreign Private Law Systems. Volume I]. Budapest: Egyetemi nyomda.

Szladits, K. (1941) Magyar magánjog. Első kötet [Hungarian Private Law. Volume one]. Budapest: Grill Károly Könyvkiadóvállalata.

Tóth J., Z. (2016) 'Legislation, Judicature and Constitutional Judicial Review: The Enforcement of Substantive Justice in the Practice of the Constitutional Court of Hungary' in Ethical Economic Thinking and Competitiveness. Budapest: Károli Gáspár University of the Reformed Church in Hungary, pp. 118-124.

Vékás, L. (1998) 'A magánjog gazdasági elemzése [Economic analysis of private law]', Állam- és Jogtudomány, 39(1-2), pp. 3-19.

Windscheid, B. (1873) Lehrbuch des Pandektenrechts. Erster Band. Düsseldorf: Verlagshandlung von Julius Buddeus.

Wróblewski, J. (1969) 'Legal Reasonings in Legal Interpretation', Logique et Analyse, 12(45), pp. 3-31.

Zlinszky, I. (1902) A magyar magánjog mai érvényében különös tekintettel a gyakorlat igényeire [Private Law in its Current Form in Hungary with Particular Reference to the Practical Needs]. Budapest: Franklin-Társulat. 